\title{
Review on Cellular, Molecular and Industrial level Role of Microbial Enzymes
}

\author{
Marya Bibi ${ }^{1}$, Gulnaz Ashraf ${ }^{2}$, Muhammad Omer Iqbal ${ }^{3}$, Maria Rafiq ${ }^{2 *}$, Hafiza Yusra Nazeer ${ }^{4}$ \\ ${ }^{1}$ College of Plant Sciences and Technology, Huazhong Agriculture University, China \\ ${ }^{2}$ Department of Biochemistry, University of agriculture Faisalabad, Pakistan \\ ${ }^{3}$ Shandong Provincial Key Laboratory of Glycoscience and Glycoengineering, School of Medicine and Pharmacy, Ocean University of \\ China, Qingdao, Shandong 266003, China \\ ${ }^{4}$ Department of Pharmacology, Bahauddin Zakariya University, Multan, Pakistan
}

*Corresponding author: Maria Rafiq

\section{Abstract}

Enzymes act as a biocatalyst that particularly catalyzed the reactions in the living organism by them to carry out the reaction. Enzymes have application in food, detergent, pharmaceutical and paper industries. Nowadays, the enzymatic hydrolysis and enzyme-based processes are preferred to the chemical ones due to the environmentally friendly nature, efficient process control, high yield, low refining costs and process safety. There are many enzymes that are used in different industries for the production of chemicals, drugs as well as other pharmaceutical products. Synthesis of enzymes can be carried out in different ways such as organic as well as inorganic synthesis but it depends upon on the nature of chemicals and reagents used for their synthesis both in laboratory and industrial level. Xylan is the major compounds found in the inner part of hemicullulose to make the cell of plants thicker as compares to the other cells. Ligninase as one of the important industrial based enzyme used to control the pollution in the environment. This enzyme has biotechnological applications in the fields of agricultural sciences for the production of agricultural products. Lipase is one enzyme that is used in fat metabolism for catalysis the fat molecules. It has also other activities other than digestion such as transportation of lipids in the form of triglycerides.

Keywords: Microbial Enzymes, Pharmaceutical applications, agriculture, industrial role.

Copyright (C) 2021 The Author(s): This is an open-access article distributed under the terms of the Creative Commons Attribution 4.0 International License (CC BY-NC 4.0) which permits unrestricted use, distribution, and reproduction in any medium for non-commercial use provided the original author and source are credited.

\section{INTRODUCTION}

There are many enzymes that are used in different industries for the production of chemicals, drugs as well as other pharmaceutical products. Synthesis of enzymes can be carried out in different ways such as organic as well as inorganic synthesis but it depends upon on the nature of chemicals and reagents used for their synthesis both in laboratory and industrial level $[1,2]$. Organic synthesis of enzymes gains more attention as compared to the other processes because of low costs and high quality products can be archived through organic synthesis. The other advantages of using the organic synthesis is the production of products that are further used for synthesis of other compounds. These compounds finally act as main source for industrial and commercial scale to increase the economy of enzymes [3-5].
Different variety of enzymes have been used in industries because as hydrolytic enzymes. These enzymes mainly act on the different substances and convert them into smaller or lesser molecules. One of the best hydrolytic enzymes is the protease that is involves in the breakdown of proteins and its related compounds [6]. These are most commonly used hydrolytic enzymes used in the dairy as well as detergent industries for through high action to degrade them. Different carbohydrates like enzymes are to breakdown the cellulose that can be breakdown by the action of cellulases that can be utilized by the animals. Hence, used for the animal breakdown of carbohydras [7].

Enzymes have extensive biochemical applications in food, pharmaceutical and petrochemical industries. Their use as a biocatalysts significantly 
increased the formation of products by formation of the useful compounds. Different enzymes have different properties depends upon the nature, and catalytic properties. Enzymes can be classified into different classes according to the functions catalyzed by them [8, 9].

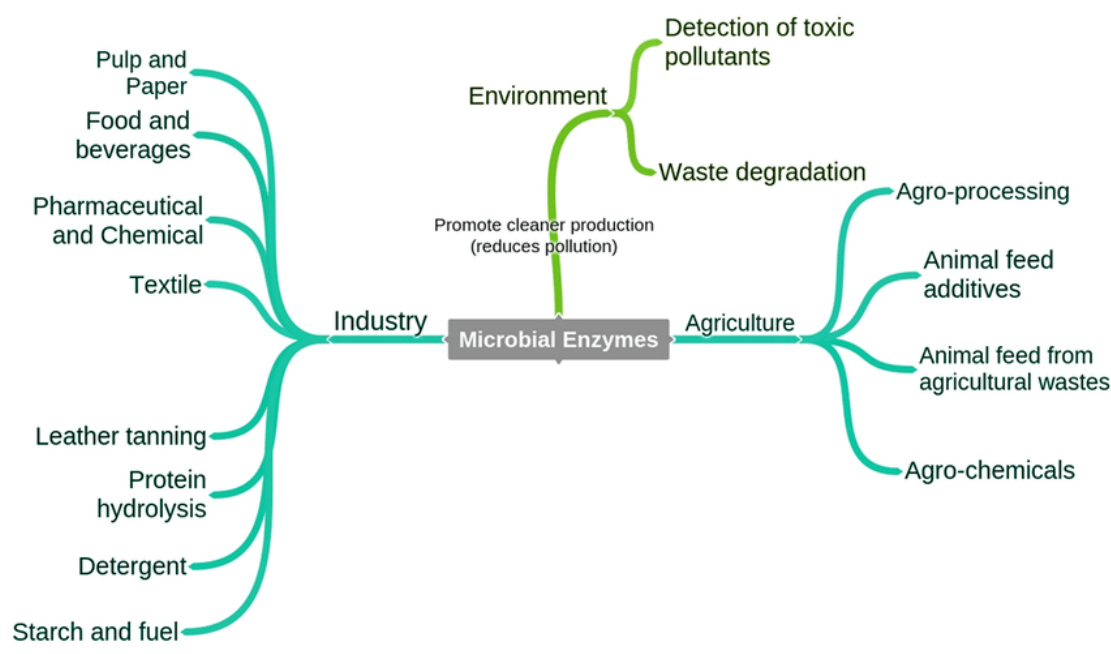

Fig-1: Shows the biological role of microbial enzymes ion different fields

\section{Biological Role of Xylanase}

Different products can be obtained from different plants due to formation of productions and useful compounds. One of the useful compounds in the plant is the hemicullulose. Xylan is the major compounds found in the inner part of hemicullulose to make the cell of plants thicker as compares to the other cells. One of the importance enzyme is the xylosidase that catalyze the breakdown of xylan in hemicullulose. It has two forms that is alpha as well as bet form that is most active for its breakdown. It is used used for the production of the juices as well as in agricultural applications. It also sued in pharmaceutical industries because of its nature acting on the medicinal plants. Hence, it can be utilized as a biological biocatalyst for different industries purposes [10-12].

\section{Biological Role of Ligninase}

Ligninase as one of the important industrial based enzyme used to control the pollution in the environment. It is also used for the process of bioremediation by acting as the main agent for waste products to degrade them into smaller substances. These waste products then recycled into other useful compounds for formation of new substances employed in the industries. It also control the xeneobiotics that are toxic to the body. Xenbiotics are the most dangerous and harmful compounds produced. These compounds should be remove from the body in order to minimize the effects caused by the xeniobiotcs and its related compounds. It has also applications in the fields of agriculture for breakdown the lignocellulose materials obtained from plants [13-15].

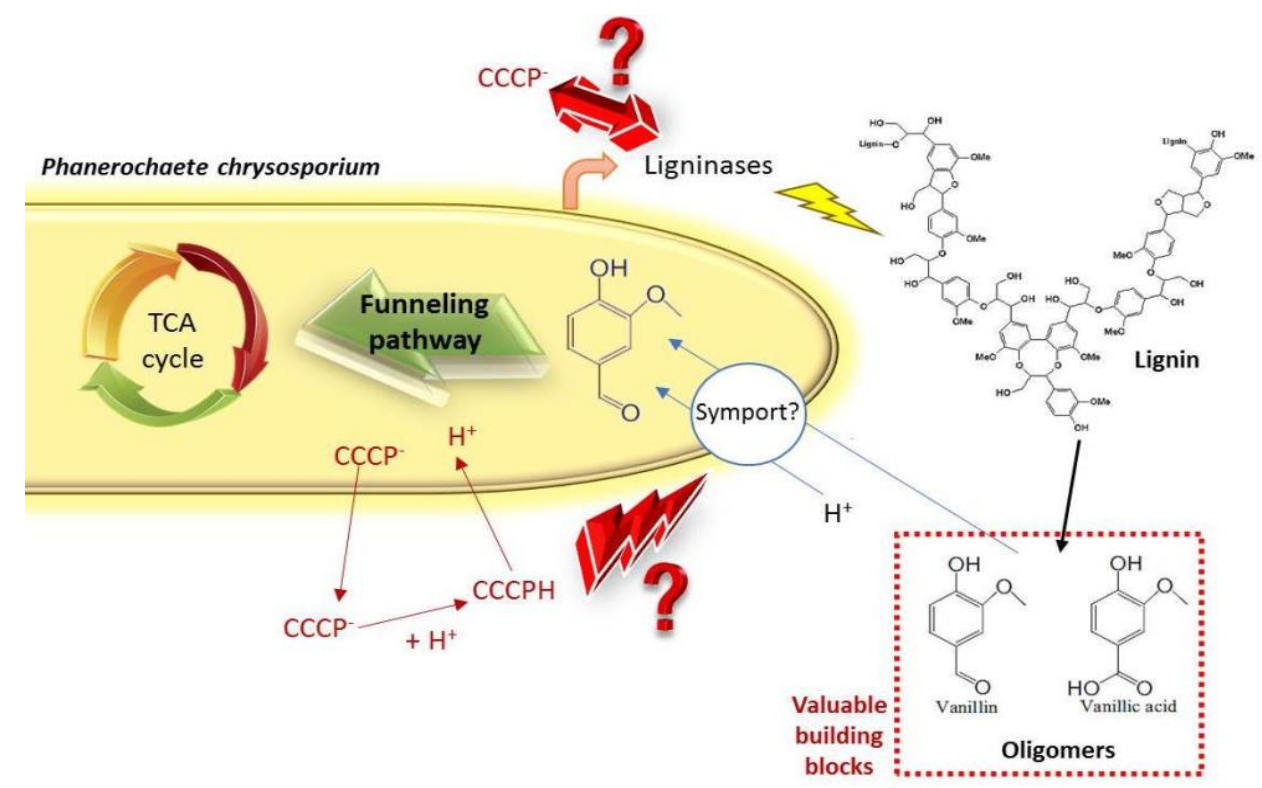

Fig-2: Shows the mechanism of action of ligninases basis 


\section{Biological Role of Fungal Amylase}

Fungal amylase is extensively used enzyme at industrial level obtained from different sources of plant such as penicillin species. This enzyme has biotechnological applications in the fields of agricultural sciences for the production of agricultural products. Some species of fungi also produce fungal amylase to activate the cellular processes that could be utilized for the synthesis of industrial compounds. It also acts at cellular and molecular level for the expression of variety of proteins in penicillin species. Defect in specific part of this enzyme lead to abnormal production of proteins that untruly leads to cellular toxicity [16-18].

\section{Biological Role of Lipase}

Many enzymes are used for the breakdown of fats into smaller molecules by the action of some important agents that balanced the reaction in right direction. Lipase is one of the such as enzyme that is used in fat metabolism for catalysis the fat molecules. It has also other activities other than digestion such as transportation of lipids in the form of triglycerides. Lipase acts in the body of animals to regulate the extra fat deposition. It also used as a main source in different industries especially medical field [19-21].

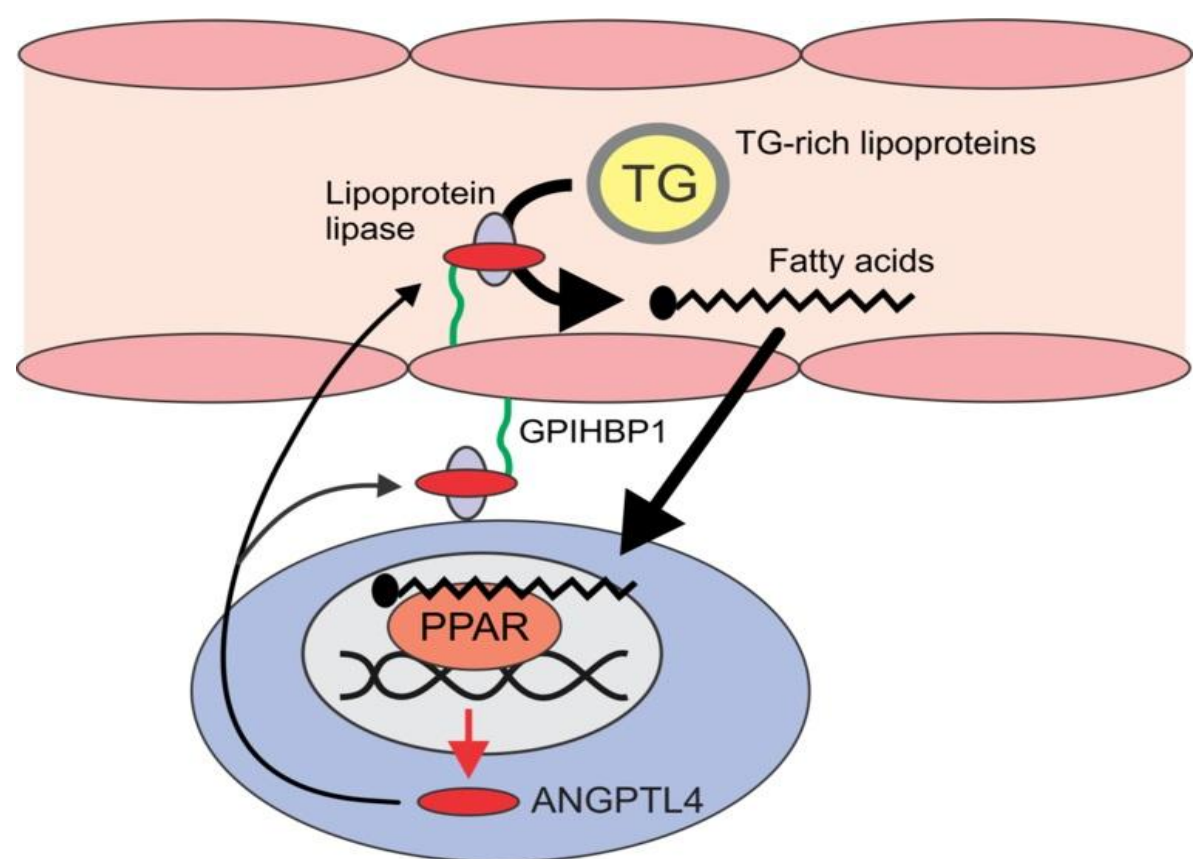

Fig-3: Shows the biological role of lipase at cellular and molecular level

\section{Applications in Pharmaceutical and analytical industry}

Enzymes have different applications in the fields of medical and health sciences such as ELISA and proteins testing. These tests can be performed in the presence of specific enzymes that catalyzed the reactions. ELISA is the test used to perform the antibodies and their concentration check to find the specific proteins in the tissue or fluids. It also helpful to diagnose the cancer as well as the hepatitis while on the other hand, proteins purification have been made immense responding to specific antigens. Purified that purified can be used for assisting the status of diseases in particular way [22-24].

Enzyme applications in medicine are as extensive as in industry and are growing rapidly. At present, most prominent medical uses of microbial enzymes are removal of dead skin, and burns by proteolytic enzymes, and clot busting by fibrinolytic enzymes. Nattokinase (EC 3.4.21.62), a potent fibrinolytic enzyme, is a promising agent for thrombosis therapy [25].

\section{Use in Food Industry}

There is an extensive use of amylase in processed food industry such as baking, brewing, production of cakes, preparation of digestive aids, fruit juices, and starch syrups. The $\alpha$-amylases have been used in the baking industry widely [26]. These enzymes are generally added to the dough of bread in order to degrade the starch into smaller dextrins, which are further fermented by the yeast. The $\alpha$-amylase enhances the fermentation rate and the reduction of the viscosity of dough, which results in improvements in the volume and texture of the product [27]. 


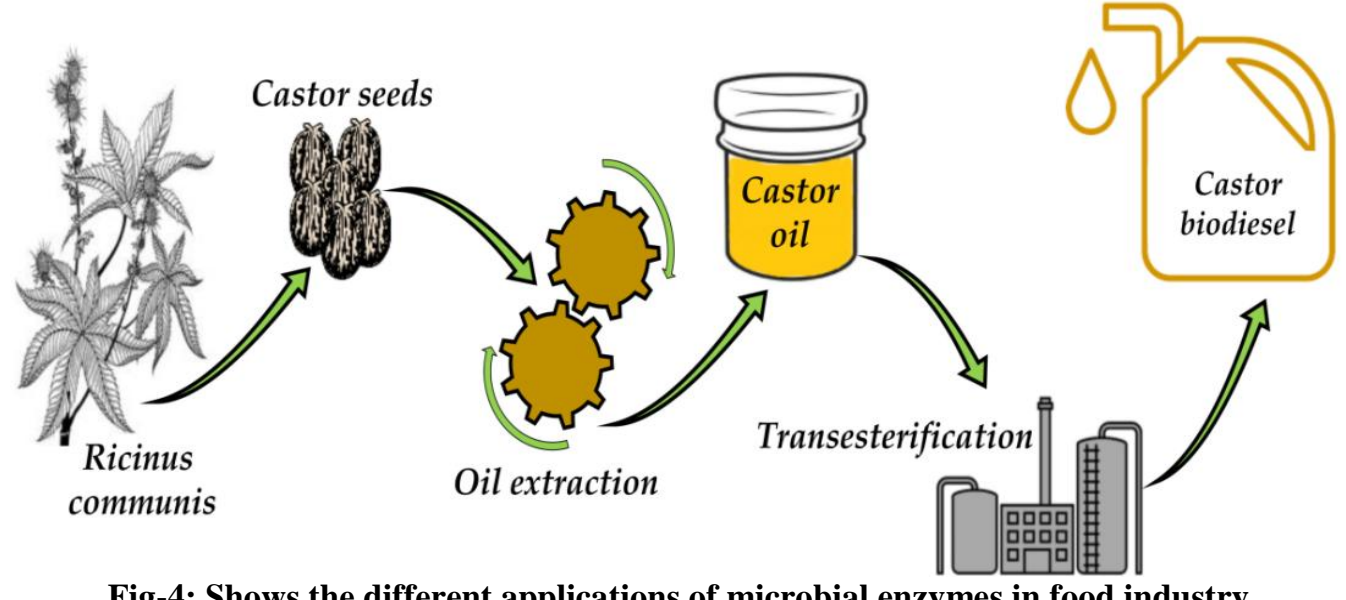

Fig-4: Shows the different applications of microbial enzymes in food industry

Bacteria employ several classes of PGNhydrolyzing enzymes that participate in assembly and disassembly of the bacterial cell wall during the processes of bacterial growth and division. PGNhydrolyzing enzymes that bind to and degrade intact bacterial cells or PGN of the producing organism are classified as autolysins. Several pathogenic bacterial species have hydrolases or autolysins that are required for bacterial pathogenicity in eukaryotic hosts [28].

Bacterial cell walls are synthesized in part through a complex reaction cycle which occurs in the membrane of the cell. The intracellular precursors of the peptidoglycan (UDP-acetylmuramylpentapeptide, UDP-acetylglucosamine and other substances) are utilized in this process to form a repeating disaccharidepeptide unit of the cell wall (which is to some extent genus specific). This unit is then added to a growing peptidoglycan chain at the outside of the cell membrane. A lipid in the cell membrane, identified as a $\mathrm{C}_{55}$ isoprenyl phosphate, functions as the membrane carrier for the hydrophilic activated disaccharidepeptide unit, transferring it to the site of its utilization at the outside of the membrane [29].

Enzymes have application in food, detergent, pharmaceutical and paper industries. Nowadays, the enzymatic hydrolysis and enzyme-based processes are preferred to the chemical ones due to the environmentally friendly nature, efficient process control, high yield, low refining costs and process safety. In comparison with plant and animal enzymes, microbial enzymes can be produced very effectively by different fermentation techniques like solid-state and submerged fermentations. It is also easy to produce microbial enzymes on a large scale. The microbial enzymes can be easily modified through various molecular and biochemical approaches. Hyperproduction of microbial enzymes with high specific activity can be achieved by overexpression of their genes. Many of the enzymes of microbial origin are still unexplored and there are many opportunities for finding wider industrial application of microbial enzymes, especially in food sector [28, 29].

Many of the enzymes which catalyze the formation of this repeating disaccharide-peptide unit of the peptidoglycan are membrane bound proteins. Thus, the study of these proteins may yield a great deal of information in general about the nature of enzymes which are localized in the cell membrane. The purpose of this presentation is to describe several such membrane proteins which have been obtained from different microorganisms [30].

\section{CONCLUSION}

Enzymes act as a biocatalyst that particularly catalyzed the reactions in the living organism by them to carry out the reaction. If there any defect in enzymes, then reactions leads to increase the speed at the optimum level. It also leads the denaturation of specific proteins that are important for the cells. Therefore, enzymes are the most important for catalyzing the reaction in the body. Defect as well as insufficient concentrations of enzymes leads to fail the particular reaction. It results the defective synthesis of proteins that causing the cells to death. Enzymes are used in the field so of medicine, industries also for industries to catalyze the specific reaction.

\section{REFERENCES}

1. Fu, X., Liao, Y., Cheng, S., Xu, X., Grierson, D., \& Yang, Z. (2021). Nonaqueous fractionation and overexpression of fluorescent- tagged enzymes reveals the subcellular sites of $\mathrm{L}$ - theanine biosynthesis in tea. Plant biotechnology journal, 19(1), 98.

2. Yin, J., Li, F., Zhou, Y., Mou, M., Lu, Y., Chen, K., ... \& Zhu, F. (2021). INTEDE: interactome of drug-metabolizing enzymes. Nucleic Acids Research, 49(D1), D1233-D1243.

3. Barghout, S. H., \& Schimmer, A. D. (2021). E1 Enzymes as Therapeutic Targets in Cancer. Pharmacological Reviews, 73(1), 1-56. 
Marya Bibi et al., Sch Bull, Apr, 2021; 7(4): 87-92

4. Shahid, A., Ali, S., Zahra, T., Raza, M., Shahid, A., Saeed, M. U., \&amp; Javaid, F. (2020). Influence of Microbes in Progression of Cancer and DNA Damaging Effects. Haya: Saudi J. Life Sci, 5(11), 246-252.

5. Iftikhar, A., Shahid, A., Shah, S. S., Ali, S., Raza, M., Ali, E., \&amp; Umbreen, S. Antimicrobial Activities of Selected Medicinal Plant with Potential Role of Chemical Compounds. Saudi J. Pathol. Microbiol,5(11), 466-470.

6. Qamar, M., Mustafa, G. A., Tariq, S., Rafeeq, H., Rafiq, M., Naqvi, W. Z., ... \& Kanwal, T. Novel Methods for Detection of Biological Samples, Current Direction and Future Perspectives.

7. Naeem, M., Hayat, M., Qamar, S. A., Mehmood, T., Munir, A., Ahmad, G., ... \& Hussain, A. (2019). Risk factors, genetic mutations and prevention of breast cancer. Int. J. Biosci, 14(4), 492-496.

8. Shafiq, S., Adeel, M., Raza, H., Iqbal, R., Ahmad, Z., Naeem, M., ... \& Azmi, U. R. (2019). Effects of Foliar Application of Selenium in Maize (Zea Mays L.) under Cadmium Toxicity. In Biological Forum-An International Journal (Vol. 11, No. 2, pp. 27-37).

9. Ahmad, I., Khan, S., Naeem, M., Hayat, M., Azmi, U. R., Ahmed, S., ... \& Irfan, M. (2019). Molecular Identification of Ten Palm Species using DNA Fingerprinting. Int. J. Pure App. Biosci, 7(1), 4651.

10. Usman, G., Muhammad, N., Hamza, R., Usman, I., Ayesha, A., Saqib, U., ... \& Fatima, Q. (2019). A Novel Approach towards Nutraceuticals and Biomedical Applications. Scholars International Journal of Biochemistry, 2(10), 245-252.

11. Tahir, M. F., Ali, S., Noman, M., \& Goher, M. A Novel Approach towards the Potential Effects of Chlorpyrifos on Testicular Biochemistry and Physiology of Male Sprague Dawely Rats.

12. Yang, W., Feng, H., Zhang, X., Zhang, J., Doonan, J. H., Batchelor, W. D., ... \& Yan, J. (2020). Crop phenomics and high-throughput phenotyping: past decades, current challenges, and future perspectives. Molecular Plant, 13(2), 187-214.

13. Naeem, M., Ali, J., Hassan, M. Z., Arshad, B., Rao, M. H. I., Sarmad, M. S. K., ... \&amp; Hassan, M. U. (2019). Novel Approach towards DNA Barcoding as a Tool in Molecular Biologyand Biological Activities of Cyclotides with Particular Emphasizes at Molecular Level. In Biological Forum-An International Journal, 11(2), 83-96.

14. Klibanov, A. M. (1983). Immobilized enzymes and cells as practical catalysts. Science, 219(4585), 722-727.

15. McCord, J. M. (1985). Oxygen-derived free radicals in postischemic tissue injury. New England Journal of Medicine, 312(3), 159-163.

16. Naeem, A., Saddique, S., \& Chand, S. A. (2019). Advancement and Future Directions towards Herbal Treatment for Various Diseases.
17. Stebbing, J., Phelan, A., Griffin, I., Tucker, C., Oechsle, O., Smith, D., \& Richardson, P. (2020). COVID-19: combining antiviral and antiinflammatory treatments. The Lancet Infectious Diseases, 20(4), 400-402.

18. Pakmanesh, F., Moslemi, D., \& Mahjoub, S. (2020). Pre and post chemotherapy evaluation of breast cancer patients: Biochemical approach of serum selenium and antioxidant enzymes. Caspian Journal of Internal Medicine, 11(4), 403.

19. Naeem, M., Ashraf, A., Safdar, H. M. Z., Khan, M. Q., Rehman, S. U., Iqbal, R., \& Ahmad, G. (2020). Biochemical changes in patients with chronic kidney failure in relation to complete blood count and anemia. IJB, 16(1), 267-271

20. Robicsek, A., Strahilevitz, J., Jacoby, G. A., Macielag, M., Abbanat, D., Park, C. H., ... \& Hooper, D. C. (2006). Fluoroquinolone-modifying enzyme: a new adaptation of a common aminoglycoside acetyltransferase. Nature medicine, 12(1), 83-88.

21. Syed Naeem Sajid, Arzoo Rubab, Nadia Azhar, Muhammad Naeem.2019.Global Environmental Risks Factors and Non Communicable Diseases.International Conference on Innovative Biological and Public Health Research.78.

22. Naeem, M., Hussain, A., Azmi, U. R., Maqsood, S., Imtiaz, U., Ali, H., ... \& Ghani, U. (2019). Comparative Anatomical Studies of Epidermis with Different Stomatal Patterns in Some Selected Plants Using Compound Light Microscopy. International Journal of Scientific and Research Publications, 9(10), 375-380.

23. Ahsan, M., Aslam, M., Akhtar, M. A., Azmi, U. R., Naeem, M., Murtaza, G., ... \& Shafiq, S. (2019). Effect of inoculation of three rhizobial strains on maize hybrids. Journal of Biodiversity and Environmental Sciences, 14(6), 168-177.

24. Hazafa, A., Batool, A., Ahmad, S., Amjad, M., Chaudhry, S. N., Asad, J., ... \& Ghani, U. (2020). Humanin: A mitochondrial-derived peptide in the treatment of apoptosis-related diseases. Life Sciences, 264, 2021, 118679.

25. Rafeeq, H., Ahmad, S., Tareen, M. B. K., Shahzad, K. A., Bashir, A., Jabeen, R., ... \& Shehzadi, I. Biochemistry of Fat Soluble Vitamins, Sources, Biochemical Functions and Toxicity. Haya: The Saudi Journal of Life Sciences.

26. Ghani, U., Naeem, M. Bukhari, S. S. H., Yar, G., Tariq, I., Siddique, S., Nawaz, H. A., Pal, Z. A. A., Nasim, F., \& Bukhari, S. A. H. (2019). Prevalence and Risk Factors associated with Hepatitis B and Hepatitis C and their Correlation with Inflammatory Markers among Southern Region of Punjab. Biological Forum - An International Journal, 11(2): 136-143.

27. Muhammad, N., Umair, R. A., Sarmad, A. Q., Ahmad, M., Tariq, M., \& Muhammad, A. F. (2019). Reliable vaccine production by using Risk 
Based Bioengineering Strategies. 6th International Conference on "Sustainable Agriculture in Changing Climate: Strategies and Management. 261.

28. Rafeeq, H., Arshad, M. A., Amjad, S. F., Ullah, M. H., Muhammad, H., Imran, R. K., ... \& Ajmal, H. Effect of Nickel on Different Physiological Parameters of Raphanus Sativus.
29. Pratt, D. S., \& Kaplan, M. M. (2000). Evaluation of abnormal liver-enzyme results in asymptomatic patients. New England Journal of Medicine, 342(17), 1266-1271.

30. Wagner, R. L., White, P. F., Kan, P. B., Rosenthal, M. H., \& Feldman, D. (1984). Inhibition of adrenal steroidogenesis by the anesthetic etomidate. New England Journal of Medicine, 310(22), 1415-1421. 